\title{
Features of Heavy Metal Contamination of Agricultural Soils in the Kursk Region of Russia and Economic Assessment of Restoration
}

\author{
Vladimir Tomakov ${ }^{*}$ and Maxim Tomakov \\ Southwest State University, 94, 50 Let Oktyabrya str., Kursk, , 305040, Russian Federation
}

\begin{abstract}
Kursk region of Russia has unique fertile soils. Heavy metals are among the factors that pollute the soil. The article is devoted to the study of the spatial distribution of heavy metals in soils. The relevance of the study is that the value of the soil is determined by its value for obtaining environmentally friendly agricultural products. Data on the content of heavy metals in the soil can prevent intensive cultivation of crops. The task of the work is to identify heavy metals that predominate in the soils of various landscapes of the Kursk region. The assessment of soil contamination with chemical elements was carried out in the course of geo-ecological studies of black earth soils in the Kursk region of Russia. The selected soil samples were examined by semi-quantitative spectral analysis. The results obtained were subjected to statistical processing. It was found that cobalt is the main pollutant in the vast majority of sampling points. In other zones, molybdenum, lead, zinc, and chromium predominate in approximately equal amounts. Soils in the surveyed area belong to the permissible category of contamination with chemical elements. Soil remediation should be applied in local areas.
\end{abstract}

\section{Introduction}

The problem of detection of agricultural soils contaminated with chemicals is under the control of state and local governments in different countries [1]. Attention is caused by the fact that there is an increase in the area of land subject to pollution by emissions of industrial enterprises.

Pollution affects the quality of crop production and human health. This is understandable, since it is from agricultural soils that contaminated products come, which are harmful to animals and humans. In many countries, where differentially normalize the content of heavy metals depending on the purpose of land, the maximum permissible concentrations for arable soils are much stricter than for urban soils on office and recreational sites [2].

\footnotetext{
${ }^{*}$ Corresponding author: tomakova@mail.ru
} 
The intensity of long-term emissions from industrial enterprises and the spatial distribution of pollutants are clearly established by the chemical composition and geochemical properties of soils, as it is the most stable and to some extent conservative component of landscapes.

Natural climatic conditions and soils of Kursk region are favorable for cultivation of the main types of agricultural crops and development of branches of processing of crop production. The structure of agriculture in Kursk region is dominated by crop production, the share of which in 2015 amounted to $57.4 \%$, the share of livestock products accounted for $42.6 \%$ [3]. The region is among the leaders of Russian regions in the production of agricultural products.

Agricultural lands occupy 2278.6 thousand hectares $(76.0 \%$ of the territory of the region). Their structure is dominated by agricultural land - 2099.7 thousand hectares, of which 1804.3 thousand hectares of arable land. Agricultural lands occupy 2278.6 thousand hectares $(76.0 \%$ of the territory of the region). Their structure is dominated by agricultural land-2099.7 thousand hectares, of which 1804.3 thousand hectares of arable land. The most fertile lands are represented by black soils. This is the most fertile land. The soils are distributed as follows: typical black soils $-26.1 \%$, leached black soils $-20.8 \%$, podzolic black soils - $19.9 \%$, forest dark gray- $11.4 \%$, forest gray $-10.5 \%$, floodplain slightly acidic and neutral $-8.2 \%$, sod - podzolic- $1 \%$, forest light gray $-0.8 \%$, sod-podzolic illuvial ferruginous - $0.7 \%$, meadow black soils $-0.5 \%$.

A significant environmental problem in the Kursk region is the high load on the atmospheric air, as the region has developed various types of industry and energy. The annual volume of emissions into the atmosphere is at the level of 150-170 thousand tons, which is the cause of pollution of agricultural lands with heavy metals [4, 5].

Soils have a low capacity for self-purification against heavy metals. The first period of removal of half of the initial concentration of heavy metals varies greatly in different elements and takes an extremely long period of time. It is known that lead has a high period of semi-removal from soils, it ranges from 740 to 5900 years. More dangerous cadmium has a period of semi-removal the soil from 13 to 110 years. For copper, the period ranges from 310 to 1500 years, for zinc-from 70 to 510 years [2]. For this reason, geochemical anomalies are formed in which concentrations of chemical elements often reach levels harmful to living organisms.

Increasing the content of heavy metals in the environment leads to a significant increase in their concentration in plants [6]. Cobalt and chromium oxides reduce the ability of soils is to decompose cellulose. Slowing down the decomposition of cellulose inhibits the flow of organic components for the reproduction of humus [2].

Heavy metals not only negatively affect plants and soil and groundwater, but also the soil itself. Influence, first of all, is shown in change of its biological activity. Soil microorganisms are especially susceptible to the effects of heavy elements, for this reason, lose humus black soils.

Not all of the heavy elements entering the soil in the form of pollutants are equally dangerous for plants and soil and groundwater. Many heavy metals, such as iron, copper, zinc, molybdenum, are involved in biological processes and in certain quantities are necessary for the functioning of plants, animals and humans trace elements. Metals that do not have a useful role in biological processes, such as lead and mercury, are also defined as toxic metals [6-8].

On the other hand, heavy metals and their compounds can have harmful effects on the human body, can accumulate in tissues, causing a number of diseases. Currently, Russia has a General Toxicological GOST, which divides heavy metals / metalloids into three classes according to the degree of danger [9]. 
It is impossible to underestimate the role of soil as a secondary source of pollution of the surface layer of atmospheric air, natural waters, residential and industrial environment, which affects the health of the population [10].

The task of the work is to identify heavy metals that predominate in the soils of various landscapes of the Kursk region.

Anomalies in the spatial distribution of heavy metals were identified. Anomalies coincide with zones of man-made pollution and cover areas near populated areas.

\section{Materials and methods}

Products of technogenic activity, falling on the earth's surface, accumulate in the upper horizons of soils and are included in natural cycles. According to the geochemical change in soil composition relative to the accepted background values, it is possible to judge the degree of their technogenic transformation.

Assessment of soil contamination by chemical elements was carried out during geoecological studies by specialists of the scientific and production company "Horse" [11]. The selected soil samples were examined by semi-quantitative spectral analysis. The obtained results were subjected to statistical processing taking into account the selected landscapes. The contents of the following elements were determined in all samples: $\mathrm{Mn}, \mathrm{Ni}$, $\mathrm{CO}, \mathrm{Ti}, \mathrm{V}, \mathrm{C} 2$, Mo, W, Zr, Nb, Cn, Pb, Aq, Sb, Bi, As, Zn, Sn, Ge, Be, Ce, Ze, P, Zi, Sr, Y, $\mathrm{Ba}, \mathrm{B}$.

For the background content of the elements, their number was taken, established in the soil of the Kursk black of the standard sample within the entire region. The gross content of an element in the sample exceeding the background values by three or more times was accepted as anomalous, requiring further study in order to establish its nature of origin (man-made or natural).

\section{Results and discussion}

The amount of silver, antimony, tungsten, bismuth, arsenic, tin, germanium, beryllium, cerium, lanthanum, yttrium, lithium, strontium, boron in a small number of samples was below or at the level of the detection limit. Therefore, the results of analyses on these elements were not subjected to statistical processing. The following is a description of the chemical elements prevailing in the soils of different landscapes.

Manganese belongs to the third class of danger, has a General toxic, carcinogenic and mutagenic effect at significant concentrations. The maximum permissible concentration (MPC) of this element, according to the General sanitary index of harmfulness is 1500 $\mathrm{mg} / \mathrm{kg}$ (gross content). The average gross content of it in the soil varies from 300 to 320 $\mathrm{mg} / \mathrm{kg}$ in landscapes with gray forest soils, up to $360 \mathrm{mg} / \mathrm{kg}$-in landscapes with black soils. The value of $340 \mathrm{mg} / \mathrm{kg}$ was revealed in the soils of the floodplain-meadow landscape. In the soils of watershed landscapes with forest soils, the content at the level of $1000 \mathrm{mg} / \mathrm{kg}$ was revealed. The excess over the background content $(596 \mathrm{mg} / \mathrm{kg})$ is less than two times and does not reach the MPC.

Nickel belongs to the second class of danger and has a General toxic, mutagenic and carcinogenic effect. Its MPC in a mobile form is $4 \mathrm{mg} / \mathrm{kg}$. The Average gross content of it in the soil ranges from $24 \mathrm{mg} / \mathrm{kg}$ in the superaqual floodplain-meadow landscape to 42 $\mathrm{mg} / \mathrm{kg}$ in landscapes with black soils of watersheds and watershed slopes. Intermediate values of Nickel are found in forest soils of landscapes: eluvial-cumulative low and high terraces- $28 \mathrm{mg} / \mathrm{kg}$ and transeluvial-eluvial watersheds and watershed slopes-33 mg / $\mathrm{kg}$. 
The maximum contents at the level of $80 \mathrm{mg} / \mathrm{kg}$ were revealed in soils of landscapes with black. In this case, the background values $(33 \mathrm{mg} / \mathrm{kg}$ ) are exceeded only 2.5 times.

Cobalt belongs to the second class of danger and has a General toxic, allergic and mutagenic effect. The maximum permissible concentration of its mobile form is $5 \mathrm{mg} / \mathrm{kg}$. Its average content in the soils of the region ranges from $9 \mathrm{mg} / \mathrm{kg}$ in the floodplain-meadow landscape to $19 \mathrm{mg} / \mathrm{kg}$ in landscapes with black soils of watersheds and watershed slopes. The maximum values of cobalt at the level of $40 \mathrm{mg} / \mathrm{kg}$ were revealed in landscapes with black soils. At the same time, there is a fourfold excess of its content compared to the background $(10 \mathrm{mg} / \mathrm{kg})$. The most extensive area with the maximum cobalt content in the soil is located in the East of the region between the regional centers of Kshensky and Gorshechnoye (the gross cobalt content was $40 \mathrm{mg} / \mathrm{kg}$ ). Another site, smaller in area but with a similar cobalt content, is located in the South of the region on the outskirts of Oboyan city. In soil samples taken near the Northern edge of the site "Streletskaya steppe" of the state Central Chernozem biosphere reserve V. V. Alekhina, cobalt content reached 30 $\mathrm{mg} / \mathrm{kg}$, which is three times higher than the background values. These samples were taken in the East of the spot of soil contamination with cobalt with a gross content of $30 \mathrm{mg} / \mathrm{kg}$, which is formed by observation points located between the cities of Kursk and Kurchatov, Pryamitsyno district centers, Medvenka and Bolshoe Soldatskoye. Another spot with the same gross cobalt content was found in the North-West of the region. It has an elongated shape in the meridional direction, stretching from the Northern outskirts of the district center Dmitriev-Lgovsky in the North to the village of Belyaevo $10 \mathrm{~km}$ West of the village of Konyshevka.

Titanium belongs to the fourth class of danger and at significant concentrations has a carcinogenic effect. The average gross content of it in the soils of the region ranges from $2070 \mathrm{mg} / \mathrm{kg}$ in the floodplain-meadow landscape to $4140 \mathrm{mg} / \mathrm{kg}$ in the transeluvial-eluvial landscape of watersheds and watershed slopes with black soils. Gross Intermediate titanium content was established in landscapes with forest soils $(3770 \mathrm{mg} / \mathrm{kg}$ ). Maximum values of this element $(6000 \mathrm{mg} / \mathrm{kg})$ were found in landscapes with black soils and landscape of watersheds and watershed slopes with gray forest soils. The excess of these values over the background $(4500 \mathrm{mg} / \mathrm{kg})$ is 1.3 times.

Vanadium belongs to the third class of danger and causes at significant concentrations of General toxic damage to internal organs, nervous and circulatory systems, irritating and carcinogenic effect. MPC on the gross content of vanadium is $150 \mathrm{mg} / \mathrm{kg}$. The average gross content of it in the soils of the region ranges from $28 \mathrm{mg} / \mathrm{kg}$ in the floodplain-meadow landscape to $48 \mathrm{mg} / \mathrm{kg}$ in landscapes with black soils. Intermediate gross vanadium content was established in landscapes with forest soils $(39 \mathrm{mg} / \mathrm{kg})$. The maximum values of this element $(80 \mathrm{mg} / \mathrm{kg})$ were found in landscapes with black soils. At the same time, these values are close to the background ( $77 \mathrm{mg} / \mathrm{kg})$, and do not exceed the MPC.

Chrome belongs to the second class of danger. The average gross content in the soils of the region ranges from $92 \mathrm{mg} / \mathrm{kg}$ in the transeluvial-eluvial landscape of watersheds and watershed slopes with black soils to $169 \mathrm{mg} / \mathrm{kg}$ in the eluvial-accumulative landscape of low and high above-flood terraces with forest soils. Intermediate gross chromium content at the level of $108 \mathrm{mg} / \mathrm{kg}$ was found in the transeluvial-eluvial landscape of watersheds and watershed slopes with forest soils. In the superqual floodplain-meadow landscape, the values were $121 \mathrm{mg} / \mathrm{kg}$. In the eluvial-accumulative landscape of low and high abovefloodplain terraces with black soils, the level was $123 \mathrm{mg} / \mathrm{kg}$. Maximum values of chromium $(500 \mathrm{mg} / \mathrm{kg})$ were established in the eluvial-accumulative landscape of low and high above-floodplain terraces with black soils. At the same time, these values exceed the background $(82 \mathrm{mg} / \mathrm{kg}$ ) by six times. The highest chromium content in soils is found near the Eastern outskirts of the village Karl Liebknecht. In addition to this site, three more sites 
revealed chromium content in the soil at the level of $300 \mathrm{mg} / \mathrm{kg}$, exceeding the background by 3.6 times. This is the territory of Rylsk, Oboyan areas and Zheleznogorsk sity.

Molybdenum belongs to the second class of danger and has a General toxic, carcinogenic and mutagenic effect at significant concentrations. The average gross content of it in the soils of the region ranges from $0.9 \mathrm{mg} / \mathrm{kg}$ in the superaqual floodplain-meadow landscape to $1.7 \mathrm{mg} / \mathrm{kg}$ in the eluvial-cumulative landscape of low and high abovefloodplain terraces with chernozem soils. Slightly lower molybdenum content was found in the eluvial-cumulative landscape of low and high floodplain terraces with forest soils (1.6 $\mathrm{mg} / \mathrm{kg}$ ), in the transeluvial-eluvial landscape of watersheds and watersheds with black soils $(1.5 \mathrm{mg} / \mathrm{kg})$ and in the transeluvial-eluvial landscape of watersheds and watersheds with forest soils $(1.3 \mathrm{mg} / \mathrm{kg})$. The maximum content of molybdenum at the level of $4 \mathrm{mg} / \mathrm{kg}$ was found in the transeluvial landscape of watersheds and watershed slopes with black soils. At the same time, this value is four times higher than the background $(1 \mathrm{mg} / \mathrm{kg})$. Within Kursk region three such sites (Kastorensky, Gorshechensky and Kurchatov areas) are revealed.

Zirconia has a significant amount of General toxic effect. The average gross content of it in the soils of the region ranges from $54 \mathrm{mg} / \mathrm{kg}$ in the superaqual floodplain-meadow landscape to $180 \mathrm{mg} / \mathrm{kg}$ in the eluvial-accumulative landscape and forest soils of high above-floodplain terraces. Intermediate values of average gross Zirconia content (130 $\mathrm{mg} / \mathrm{kg}$ ) were established in the transeluvial-eluvial landscape of watersheds and watershed slopes with forest soils, as well as in landscapes with black soils $(128 \mathrm{mg} / \mathrm{kg})$. The maximum contents at the level of $400 \mathrm{mg} / \mathrm{kg}$ occur in almost all landscapes of the region except for one-superaqual floodplain-meadow, where the highest concentration was only $100 \mathrm{mg} / \mathrm{kg}$. the recorded values are less than the background value $(450 \mathrm{mg} / \mathrm{kg})$.

Niobium, getting into the body, inhibits the activity of enzymes. The background value of niobium is $17 \mathrm{mg} / \mathrm{kg}$. The average gross content of it in the soils of the region ranges from $1.1 \mathrm{mg} / \mathrm{kg}$ in the floodplain-meadow landscape to $13 \mathrm{mg} / \mathrm{kg}$ in the eluvialaccumulative landscape of low and high above-floodplain terraces with forest soils. Intermediate values of average gross contents of niobium are established in landscapes with black soils $(10 \mathrm{mg} / \mathrm{kg})$ and transeluvial-eluvial landscape of watersheds and watershed slopes with forest soils $(8.4 \mathrm{mg} / \mathrm{kg})$. The maximum contents at the level of $30 \mathrm{mg} / \mathrm{kg}$ were found in almost all landscapes of the region, except for one-floodplain-meadow, where the highest concentration was only $3 \mathrm{mg} / \mathrm{kg}$.

Copper belongs to the second class of danger and has a General toxic, mutagenic effect. The value of its MPC is $3 \mathrm{mg} / \mathrm{kg}$ (mobile form). The average gross content of it in the soils of the region ranges from $9 \mathrm{mg} / \mathrm{kg}$ in the superaqual floodplain-meadow landscape to 16 $\mathrm{mg} / \mathrm{kg}$ in landscapes with black soils. Intermediate values were established in landscapes with forest soils at the level of 12 and $14 \mathrm{mg} / \mathrm{kg}$. Maximum amounts of copper at the level of $40 \mathrm{mg} / \mathrm{kg}$ were found in the transeluvial-eluvial landscape of watersheds and watershed slopes with black soils. These values exceed the background values $(22 \mathrm{mg} / \mathrm{kg})$ twice.

Lead belongs to the chemical substance of the first class of danger and has a General toxic, carcinogenic, mutagenic, teratogenic, gonadotoxic effect, has a cumulative effect and causes damage to the central and peripheral nervous system. The MPC total content is 30 $\mathrm{mg} / \mathrm{kg}$. The average gross lead content in the soil of the floodplain-meadow landscape is from $6 \mathrm{mg} / \mathrm{kg}$ to $22 \mathrm{mg} / \mathrm{kg}$ in eluvial-cumulative landscapes and high above-floodplain terraces, respectively, with forest and chernozem soils. Intermediate values were established in transeluvial-eluvial landscapes of watersheds and watershed slopes with forest $(15 \mathrm{mg} / \mathrm{kg})$ and black soils $(18 \mathrm{mg} / \mathrm{kg})$ soils. The maximum gross lead content at the level of $100 \mathrm{mg} / \mathrm{kg}$ was revealed in the eluvial-accumulative landscape of low and high 
above-floodplain terraces with black soils. At the same time, it is 3.3 times higher than the MPC $(30 \mathrm{mg} / \mathrm{kg}$ ) and 6.2 times the background values $(16 \mathrm{mg} / \mathrm{kg})$. Individual samples with a lead content exceeding the MPC were found in almost all landscapes with both forest soils and black soils, except for the superqual floodplain-meadow landscape, where its highest amount was $0.3 \mathrm{MPC}$. The site with the highest content of lead in soils $(100 \mathrm{mg} / \mathrm{kg})$ was identified on the southern outskirts of the village of Kshensky. The other two sites are located near the village of Kastory and the city of Rylsk. The content of lead here is $50 \mathrm{mg} /$ $\mathrm{kg}$, which is 1.6 times higher than the MPC. In the city of Oboyan near the landfill of household waste in the village of Tim, on the Northern outskirts of Dmitriev city and in the village of Deryugino, Dmitrievsky district, the lead content in the soil is $40 \mathrm{mg} / \mathrm{kg}$.

Zinc belongs to the chemical substance of the first class of danger and has a General toxic, carcinogenic effect. Its MPC of mobile forms is $37 \mathrm{mg} / \mathrm{kg}$. the Average gross zinc content in the soils of the region ranges from $37 \mathrm{mg} / \mathrm{kg}$ in the superaqual floodplainmeadow landscape to $80 \mathrm{mg} / \mathrm{kg}$ in the transeluvial-eluvial landscape of watersheds and watershed slopes with black soils. The zinc content in the soils of other selected landscapes is intermediate, varying from 53 to $69 \mathrm{mg} / \mathrm{kg}$. Maximum concentrations of zinc (200 mg / $\mathrm{kg}$ ) were found in the transeluvial-eluvial landscape, watersheds and watershed slopes with black soils and in the eluvial-accumulative landscape of low and high above-floodplain terraces with forest soils. The excess of these contents over the background is almost 4 times. Within the region there are only two sites where the concentration of zinc in the soil exceeds the background by three or more times: near the village of Tim and in Rylsk city. The zinc content in the soil here was $200 \mathrm{mg} / \mathrm{kg}$, which is 3.85 times higher than the background values $(52 \mathrm{mg} / \mathrm{kg})$.

Assessment of the level of chemical pollution of soils as an indicator of adverse effects on public health was carried out according to the indicators used in the combined geochemical and sanitary-epidemiological studies of the environment. These indicators are: the concentration coefficient (CS) of the chemical and the total pollution index (ZC). According to these characteristics, a map of the total indicators of soil pollution by chemical elements is constructed. Assessment of soil contamination hazard by complex elements on the indicator ZC was carried out in accordance with the scale developed by the Ministry of health of the Russian Federation. Based on the results obtained during the works of scale 1: 500000 on the territory of the region, it can be concluded: the soils of the entire territory of the Kursk region belong to the permissible category of contamination with chemical elements. However, local areas of soil with a high level of pollution require detailed inventory and remediation by known methods $[12,13]$.

\section{Economic justification of the effectiveness of reclamation methods}

The assessment of economic efficiency and remediation technologies is one of the most difficult environmental problems. When comparing the costs of phytoremediation and land use of a land plot with an area of $1 \mathrm{ha}$, it was found that the costs of phytoremediation were 1095000 rubles, land use - 7597000 rubles. The cost of conducting phytoremediation consisted of the technological costs incurred in the cultivation of phytoremediation plants (90 years, 16 repetitions according to the scheme: alfalfa, mountaineer, sverbiga, esparcet) and land use - from the cycle of reclamation operations (10 years). 


\section{Conclusions}

Cobalt is in the vast majority of sampling points, the main pollutant element. In other zones molybdenum, lead, zinc and chromium prevail in approximately equal quantities.

For five elements: $\mathrm{Mo}, \mathrm{Pb}, \mathrm{Co}, \mathrm{Cr}, \mathrm{Zn}$, the gross contents of which exceeded the background values by three or more times, maps of their concentrations were made. Maps reflect the spatial distribution of heavy metals in soils, showing their concentrations.

Anomalies coincide spatially with zones of technogenic pollution. The distributions have a focal character and cover the territories near settlements, which is a consequence of the technogenic impact of industrial enterprises of chemical, machine-building and heatpower industries. The need for selective soil remediation measures is obvious.

Phytoremediation of technogenically polluted soils is a technological technique characterized by a low cost of application. Phytoremediation uses solar energy and compared, for example, with land use or the removal of polluted soils, technology has a significantly higher agro ecological, economic and energy efficiency.

\section{References}

1. Vodyanitskii Y.N. Current trends of soil pollution by heavy metals. Agrochemistry. 9: 88-96 (2013)

2. Vodyanitskii Y.N. Contamination of soils with heavy metals and metalloids and its ecological hazard (analytic review). Eurasian Soil Science. 46(7): 793-801 (2013)

3. Agriculture of Kursk region. URL: https://ab-centre.ru/page/selskoe-hozyaystvokurskoy-oblasti

4. Skripko T.V., Mal'gina I.L. Environmental consequences of soil contamination with heavy metals. Successes of modern natural science. 6: 1015-110 (2019)

5. Bashkin V.N., Galiulin R.V., Galiulin R.A., Arabsky A.K. Risk of soil contamination by heavy metals as a result of gas and dust emissions. Problems of risk analysis. 16(1): 4249 (2019)

6. Batova Yu.V., Kaznina N.M., Titov A.F., Laidinen G.F. State of herbaceous vegetation and accumulation of heavy metals by plants growing in conditions of technogenic soil pollution. BulletinTambov University. Series: Natural and technical Sciences. 19(5):1642-1645 (2014)

7. Vodyanitskii Y.N. Standards the contents heavy metals and metalloids in soils. Eurasian Soil Science. 45(3): 321-328 (2012)

8. Suldina T.I. The content of heavy metals in food and their impact on the body. Rational nutrition, food additives and biological stimulants. 1: 136-140 (2016)

9. State report "On the state and environmental protection of the Russian Federation in 2017" (Moscow: Ministry of natural resources of Russia; NCE "Cadastre", 896 p. 2018)

10. Sivukhin A.N., Markov D.S., Borisova E.A. Influence of soil pollution by heavy metals on the health of the population of Ivanovo and Kostroma regions. Problems of regional ecology. 3: 81-87 (2019)

11. Report on the state of the environment of the Kursk region in 1999. State committee for environmental protection of Kursk region (Kursk, 140 p., 2000)

12. YAnin E.P. Remediation of territories contaminated with chemical elements: General approaches, legal aspects, main methods (foreign experience). Problems of the environment and natural resources. 3: 3-105 (2014)

13. Babaeva T.M. Phyto melioration clearing of soils contaminated with heavy metals. Bulletin of Science and Practice. 5(9): 234-238 (2019) 